\title{
Working in a Paid Job Effects on Breastfeeding in Turkey: A Qualitative Study
}

\author{
(D) Emine Ayhan, ${ }^{1}$ (D) Alaettin Ünsal, ${ }^{2}$ (D) Didem Arslantaş² \\ 'Department of Public Health, Giresun University Faculty of Medicine, Giresun, Turkey \\ ${ }^{2}$ Department of Public Health, Eskişehir Osmangazi University Faculty of Medicine, Eskişehir, Turkey
}

\section{ABSTRACT}

Objectives: Breast milk is the ideal food for babies and breastfeeding infants for the first six months is important for infant health. A mother's breastfeeding behavior depends on several factors, such as the social position and employment status of the mother.

Methods: This study is a qualitative study conducted in Eskişehir Osmangazi University (ESOGU) office workers and cleaning staff. This study was carried out to reveal the effects of working in a paid job on breastfeeding using the feelings, thoughts and experiences of nursing women working as office workers and cleaning staff. ESOGU has 1106 women as working staff. The research population consisted of 45 (4.1\%) women who have been working as office staff and cleaning workers between September 1, 2014, and March 01, 2015, had infants under two years old and returned to work life.

Results: This research was conducted at ESOGU with 35 women. The findings showed that the maternity leave and breastfeeding rights of the women employed were insufficient and this situation had a negative effect on the breastfeeding.

Conclusion: It was determined that working women in workers' status have fewer rights than civil servants. As a result, breastfeeding room deficiencies should be completed. The recognition of equal rights to all women during the breastfeeding periods is strongly recommended.

Keywords: Breast feeding, maternity leave, Turkey, qualitative research, working woman

\section{INTRODUCTION}

Address for correspondence: Dr. Emine Ayhan. Department of Public Health, Giresun University Faculty of Medicine, Giresun, Turkey

Phone: +90 5052481735

E-mail:

dr.emineayhan@gmail.com

Received Date: 21.08 .2019

Accepted Date: 06.11.2019

Published online: 01.04.2020

CCopyright 2020 by Anatolian Journal of Family Medicine -

Available online at www.anatoljfm.org

OPEN ACCESS

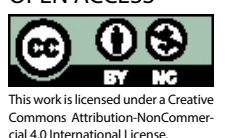

Breast milk is the ideal food for babies' growth and development. The World Health Organization, the United Nations Children's Fund and the American Children's Academy emphasized that only breastfeeding of infants for the first six months is important for infant health. It is recommended to continue breastfeeding with additional foods after the sixth month. ${ }^{[1-3]}$

A mother's breastfeeding behavior depends on the several factors, such as the required and adequate feeding time of the infant's breastfeeding, the time of first breastfeeding, the frequency of breastfeeding, the time to switch to supplementary foods, the social position and employment status of the mother. Breastfeeding is known to be terminated before the recommended time because of various reasons, such as the mother's return to the work after birth. ${ }^{[4,5]}$

It has been reported that the working mothers until they start to work after birth have similarities with the mothers who do not work concerning breastfeeding period ${ }^{[6]}$ Also, the mothers who return to work after the birth leave breastfeeding earlier than required or they switch it to additional food before six months because of the insufficient information on breastfeeding, negative working conditions in the workplace and the changing the infant $\operatorname{diet}^{[7,8]}$ In some studies, it has been emphasized that prolongation of returning time to the working life of the mothers after birth increases breastfeeding time. ${ }^{[9,10]}$ 
This study was carried out to investigate the effects of working in a paid job on breastfeeding using emotions, thoughts and experiences of women working as office workers and cleaning staff at Eskişehir Osmangazi University in Turkey (ESOGU).

\section{METHOD}

This research was carried out at ESOGU. ESOGU is a 42 years old university with 11 faculties, four schools, one state conservatory, four vocational schools and five institutes. ${ }^{[1]]}$

This study is a qualitative study conducted in ESOGU office workers and cleaning staff. This study was carried out to reveal the effects of working in a paid job on breastfeeding using the feelings, thoughts and experiences of nursing women working as office workers and cleaning staff. This research, which has a qualitative pattern, is not intended to be generalized as in all other qualitative studies.

ESOGU has 1106 women as working staff. The research population consisted of 45 (4.1\%) women who have been working as office staff and cleaning workers between September 1, 2014, and March 01, 2015, had infants under two years old and returned to work life. The selection criteria of the study group were to give birth on time, not to give birth to a twin, to have no congenital anomaly in the child, to be discharged with the baby from the postpartum hospital, to be nursed until after the birth, to be breastfeed after the return to maternity leave. In this study, 39 (86.6\%) of the 45 women on the research population were complied with these criteria, and this study was carried out with 35 (77.7\%) women who accepted to be the studied.

The eligible participants were informed about the subject and the purpose of this study and verbal approvals were received from the participants who agreed to participate in this research, and the date and place of the interview were determined. The places to be interviewed were chosen from quiet environments with the possibility of interviewing alone. The interviews were conducted by the researcher.

This study was conducted using a semi-structured interview method as a data collection technique face to face by the researcher. The questionnaire form and the questions in the semi-structured interviews, including the socio-economic and demographic characteristics of the women interviewed, were formed after the literature review in accordance with the purpose of this study. In the semi-structured interview used in the interviews, 10 open-ended questions related to the factors that might affect the breastfeeding behavior of working women were asked. ${ }^{[12-16]}$ Before starting to collect data in this study, three people working at ESOGU were interviewed as the office and cleaning staff with children under two years of age who were not included in this study to look at the functioning of the questions.

Before the start of the interviews, verbal and written approvals were obtained from the women who formed the study group. Interviews ranged from 30 to 80 minutes, with an average duration of 55 minutes. A total of 33 hours and 20 minutes of audio recordings were transferred to Microsoft Word in a digital environment for transcription and further analysis. The interviews were first analyzed and interpreted descriptively and systematically. The questions asked about the socio-economic and demographic characteristics were analyzed by the researcher. Observation notes were also used during the analyses. As a result of the analysis of decoded audio recordings, themes and subthemes (categories) were created based on the findings. Analyzes were analyzed descriptively and systematically and main and sub-themes were determined. Quantitative research data are summarized as frequency, percentage, mean and standart deviation using descriptive statistics.

\section{RESULTS}

The age of the participants constituting the study group the mean age was $32.1 \pm 5.1$ years. Some sociodemographic characteristics of the study group and the characteristics related to breastfeeding are given in Table 1 .

In this study, direct quotations were made from the participants' expressions on the effects of the women interviewed on paid work on breastfeeding, and the data were analyzed descriptively. Then, these data were classified and systematic analysis of the data was made and three salient themes and related sub-themes were formed.

One of the findings obtained in this study was "The inadequacy of legal rights, such as birth leave and breastfeeding breaks" theme and its sub-themes were determined as "Policies related to the adaptation of workplaces to women's fertility" and "The right to free birth leave and breastfeeding breaks for women working as subcontractors is more limited than the civil servants".

As a result of the information obtained from the women in our study, "Workplace working conditions" theme was created. This them was divided into three sub-themes as "Workplace environment and working conditions", "The attitude of the managers", and "The approach of colleagues".

The last theme was created as "Working mothers and their opinions on continuing to work during breastfeeding" and its sub-themes were determined as "Women's ideal perception of motherhood" and "The effects of working in a paid job on breastfeeding after the birth". 


\begin{tabular}{|c|c|}
\hline & n (\%) \\
\hline \multicolumn{2}{|l|}{ Education status } \\
\hline Primary school & $3(8.6)$ \\
\hline Middle school & $2(5.7)$ \\
\hline High school & $9(25.7)$ \\
\hline University & $21(60.0)$ \\
\hline \multicolumn{2}{|l|}{ Famil Type } \\
\hline Nuclear family & $32(91.4)$ \\
\hline Extended Family & $3(8.6)$ \\
\hline \multicolumn{2}{|l|}{ Working Status } \\
\hline Office workers & $15(42.9)$ \\
\hline Office workers (Subcontractor) & 10 ( 28.6) \\
\hline Cleaning staff & $9(25.7)$ \\
\hline Office workers (Contractual) & $1(2.8)$ \\
\hline \multicolumn{2}{|l|}{ Free Maternity Leave (months) } \\
\hline None & $15(42.8)$ \\
\hline $1-2$ & $2(5.7)$ \\
\hline $3-6$ & $17(48.6)$ \\
\hline 7 and above & $1(2.9)$ \\
\hline \multicolumn{2}{|c|}{ The Age of the Baby when the Maternity } \\
\hline \multicolumn{2}{|l|}{ Leave Ends (months) } \\
\hline $0-6$ & $16(45.7)$ \\
\hline $7-12$ & $18(51.5)$ \\
\hline 13 and above & $1(2.8)$ \\
\hline \multicolumn{2}{|l|}{ Breast Feeding Period (months) } \\
\hline $5-10$ & $7(20.0)$ \\
\hline 11 and above & $28(80.0)$ \\
\hline Total & $35(100.0)$ \\
\hline
\end{tabular}

"The inadequacy of legal rights, such as birth leave and breastfeeding breaks" theme

\section{"Policies related to the adaptation of workplaces to women's fertility"}

In our study, working mother pointed out that maternity leave and breastfeeding breaks were insufficient. Although they had the opportunity to have free permissions, they started to work before the time they planned because of the living difficulties, and they mostly stated that they preferred to have permission to complete the first six months. Until their infants were six months old, some of the working women used free permission and some of them tried to have health reports to increase the permission time:

"I had my birth permit already until the baby was 3-4 months old. A four-month time period was my maternity leave. I also had annual permission, which I have accumulated as 20 days as all in a year, and after that, I got a health report, so I could extend the permission till five and a half months in total. I really wanted to spend time with my daughter and be with her till she is two years old. My circumstances were perhaps not suitable". (Participants (P) 34, 28 years old, office worker, she returned to work when her baby was 5.5 months. She did not use free permission; her child is 22 months; she is still breastfeeding.)

One common complaint among all women interviewed was the inadequacy of their breastfeeding breaks. Women who returned to work at the end of maternity leave reported that the frequency of breastfeeding decreased. It was found that some women could not use breastfeedings breaks effectively because they were away from their homes:

"My home is very far away. There are big problems. I spend my breastfeeding breaks on the road and the buses. I go to my mother first and pick my baby up and then I go home. It takes one and a half or two hours. Sometimes, I miss the bus from here and then it takes more than two hours". (P.14, 26 years old, the officer, she returned to work when her baby was nine months, she used four months of free permission, the child is 12 months, and she is still breastfeeding).

\section{"The right to free birth leave and breastfeeding breaks for women working as subcontractors is more limited than the civil servants"}

Maternity leave and breastfeeding breaks period of the officers are more than the workers have in existing legislation in Turkey. It was expressed by women that this situation led to the feeling of inequality and injustice:

"What is the difference between me (a subcontractor) and the officer lady? She's a human as well as I'm. She sits at the table and I wipe the glass. Is it the reason my permission periods are shorter than a officer lady? But if she's a civil servant, I'm human too. She has a child-like I do". P.33, subcontractor cleaning worker, she returned to work when her baby was six months, she used two months free permission, the child is nine months, she is still breastfeeding).

\section{“Workplace working conditions"}

\section{"Workplace environment and working conditions"}

The physical conditions of the workplace should be suitable for her to continue her job and to maintain her breastfeeding at the same time. The women interviewed emphasized that they could not benefit from the nursing rooms available at the workplace effectively. The women pointed out that because of breastfeeding room conditions and breast milk storage circumstances in the workplace were not very 
well, these situations caused the descrease of breast milk, and breastfeeding was affected negatively. Some women stated that they had health problems like mastitis because they could not gather their milk:

"There is no proper room. The hygiene is already zero. Where else could it be? You can milk it in the bathroom. But I don't have a place to milk my breasts. I remember squeezing it in the sink to relax" (P. 24, 36 years old, officer, she returned to work when her baby was seven months; she did not use free permission; she extended the permission period with annual permissions and health reports; the child is 16 months old and she is still breastfeeding).

"I was very uncomfortable. There were times when my chest was swollen. I've used antibiotics twice (because of mastit). My milk channels were clogged because I couldn't milk my breasts (P. 30, 35 years old, civil servant; she returned returned to work when her baby was 5.5 months; she did not use free permission; she prolonged the permission period using annual permissions and health reports. The child is 15 months old and she is still breastfeeding).

\section{"The attitude of the managers"}

Despite the women in this study group know their legal rights in Turkey, the findings showed that because of the use of maternity leave and breastfeeding breaks were the control of their supervisiors, women's work density were not alleviated by any arrangments. The subcontractor employees were found to be unable to make any protest on the grounds because they felt there was no job security:

"I interviewed the director and I demanded three months of free permission. He gave me three months permission but l'd had the chance l'd take six months. But I couldn't get it because of business conditions" (P. 18, 29-year-old subcontractor, she returned to work when her baby was 6,5 months. She did use free permisson for three months, her child is 14 months, and she is still breastfeeding).

"I'm a company employee and I can leave the work at 15:30. Officers can leave at 14:00. At another place, Because of his supervisor is flexible, she leaves at 12:00. But if the regulation is set no one will have to give anyone a tolerance or anything else". (P. 3, 25 years old, subcontracted office worker, she returned to work when her baby was four months old, she did not use free permission. the child is 18 months and she breastfeded for eight months).

\section{"The approaches of colleagues"}

Working in a stress-free work environment is important for the continuation of milk during the breastfeeding period.
Women interviewed in our study reported that some of their co-workers think their milk leave periods were extra given times for the women. They expressed that this attitude of their colleagues led them to stress. The women said that superiors were more supportive of breastfeeding and permissions. Some women stated that the superiors had a negative attitude towards women's breastfeeding breaks because the workload of some of their colleagues increases:

"My colleagues never supported me. I do all the work myself and I leave the work at 15:30. Let me say this. Some men may think that women dont need to work and they need to take care of the child at home" (P. 15, 30 years old officer, She returned work when she was 8.5 months old. She did use free permisson for five months. The child is 14 months and she is still breastfeeding).

"My male co-worker who works in the same place always accepts files when I must leave. They don't like that I use my permissions. Men are more ruthless. My chief is a lady and she is better then single co-workers and men" (P. 9, 29 years old, the officer, she returned to work when her baby was 14 months old, she did use free permisson for one year. the child is 18 months and she breastfeded for 16 months.

\section{Working mothers and their opinions on continuing to work during breastfeeding "Women's ideal perception of motherhood"}

In the norm for traditional social maternity, the primary duty of the woman is to look at the child at home rather than working. The women interviewed in this study were found to experience deep sorrow and stress because they did not perform their maternity duties sufficiently, they deprived their children of maternal love and they thought that they could not be with their children enough.

"You can't see a lot of things of your baby. You should witness many things on your baby. He needs to learn a lot of things from you, he can't learn from others. That's why I feel so bad that I'm not with the child" (P. 5, 30-year-old, office worker, she started to work when her baby was 10 months old, she used free permission for six months, the child is 18 months and she breastfeded for 12 months).

\section{"The effect of working in a paid job on breastfeeding after the birth"}

Only breastfeeding is sufficient for the first six months of infant feeding. However, in the current law in Turkey, working women maternity leave periods with pay are less than six months. Some people in the study group during the work could not breastfeed their children, so they could 
not have enough effects from the baby that the milk was reduced. Therefore, the baby had to start to eat additional food in the first six months. Most of the women reported that they breastfeded their babies at night because they could not breastfeed enough during the day. They said that breastfeeding during the night caused them to be sleepless, causing them to quit breastfeeding earlier than they had planned.

"I was sleepless. I was very tired. Just Imagine that you get up at night 4-5 times and breastfeed for half an hour. I sleep for an hour or two. It's reflected in the child, too. This is reflected in work, fatigue, insomnia. I come with swollen eyes in the mornings. 18 (P. 9, 29-year-old, officer, she returned to work when his baby was 14 months old, she used free permission for one year, the child is 18 months old, she breastfeded for 16 months of age).

When you leave your child to babysitter, he eats additional food as a child. He used to eat, but I could breastfeed when I went home to feed him more. But the baby was depending on only milk. Thus, I thought I should leave of breastfeeding (P. 26, 34 years, subcontracted office worker, she returned to work when her baby is 11 months, she did use free permisson for 4 months, The child is 18 months and she breastsfeded for 15 months).

\section{DISCUSSION}

Working women, especially during pregnancy and breastfeeding, need more supportive policies to continue the paid work as well as to be able to breastfeed in their early periods of the children. Women are entitled to at least six months of paid maternity leave and the right to breastfeeding breaks at the end of this permit to women to start or work on a paid work. ${ }^{[17]}$ In our study, it was determined that the women interviewed found maternity leave period insufficient and especially they did not want to return to work until their babies complete the first six months. However, women's livelihood was forced to start work before the time they were determined. In some studies, it is reported that maternity leave of working women is insufficient. ${ }^{[18,19]}$

Among working women in Turkey, worker women have less maternity leave rights and breastfeeding breaks than the civil servants women and this situation formed an unequal situation in terms of spending time for the mothers and their babies. Lakati et al. reported that women who work in private sector workplaces had shorter maternal breastfeeding times than women in public workplaces. ${ }^{[20]}$ Yilmaz et al. pointed out that women who work in the status of workers had shorter breastfeeding times than women working in the public sector. ${ }^{[21]}$
Due to the changing economic and social structure in the world, women's increasing participation in business life has made the breastfeeding problem more apparent in business life. To breastfeeding women to continue breastfeeding after birth, arrangements have been made for breastfeeding breaks and working conditions in our country and in the world. ${ }^{[18,22]}$ In our study, the duration of breastfeeding breaks was insufficient and there were no breastfeeding rooms allocated for breastfeeding women. In some studies, it has been reported that the regulations in the workplaces are still insufficient. ${ }^{[23-28]}$ In addition to the inadequacy of existing legal rights related to breastfeeding, deficiencies in the implementation of legislation in workplaces have been demonstrated both in our own study and in some studies. In a study of working and breastfeeding women, Kozhimannil et al. reported that approximately half of the women could not use their daily breastfeeding breaks adequately and the workplace do not have the appropriate breastfeeding rooms. ${ }^{[28]}$ In another study by Dodgson and Chee, it was reported that approximately one quarter of the workplaces provided their employees with the possibility of breastfeeding, and one tenth gave permission to breastfeeding. ${ }^{[29]}$ Canbaz et al. in their work on hospital workers reported that women returned to work after birth could not use all of their daily breastfeeding permits. ${ }^{[30]}$

The attitudes of their supervisors have an important role in employing workers, using breastfeeding permits in their workplaces during the breastfeeding period and reducing their workloads. ${ }^{[31]}$ Some researchers reported that in the workplace, superiors did not allow their mothers to use breastfeeding permits, and it had a negative impact on their breastfeeding. ${ }^{[23,24,26]}$ In our study, it was found some of them were restricted of using breastfeeding breaks by their superiors; however, some of them were supported by female superior specially who have children.

Women who spend most of the day at workplaces need support of their colleagues during breastfeeding. ${ }^{[32]}$ Dabritz et al. reported that having colleagues who support breastfeeding in workplaces contributed positively to longer maternal breastfeeding periods. ${ }^{[33]}$ In our study, it was determined that some of the women interviewed did not receive support from their colleagues while using legal breastfeeding breaks. Controversly, their colleagues accepted these legal breaks as extra times given to women. A similar result was reported in his study in Bristow. ${ }^{[34]}$

In patriarchal societies, the ideal mother takes all the responsibility for baby care and raising the baby. The primary priority in ideal motherhood perception is that mothers continue to breastfeed. There is a respected social role 
for the mother, who is breastfeeding and only maintains domestic care. ${ }^{[35]}$ This perception may cause women to refuse to work in paid work, thinking that breastfeeding may be affected. ${ }^{[36]}$ Working women, after working as a mother during their working hours apart from their babies can not fulfill their ideal motherhood role. A sense of being unable to perform the task of motherhood can lead to a feeling of guilt in women. ${ }^{[36]}$ Bağlı and Sevim study reported that working women in paid work feel guilty because of ideal maternity pressure and because of they can not pay enough attention to their babies. ${ }^{[37,38]}$ In our study, likewisely, it was found that women group felt guilty because of the ideal maternity pressure and insufficiency of breastfeeding. To overcome this feeling of guilt, women were found to be sleepless until they breastfed their babies.

The limitations of the research, such as the research was conducted in a public institution caused the women working in the private sector to remain out of the scope and their perspectives, could not be evaluated. The academic staff could not be evaluated because thisstudy was carried out with the office workers and the cleaning staff.

\section{CONCLUSION}

As a result of this study which was conducted to investigate the effects of working women on breastfeeding using emotions, thoughts and experiences of officer workers and cleaning staff at ESOGU, the findings suggest that the maternity leave and breastfeeding rights of the women employed were insufficient and this situation had a negative effect on the breastfeeding. It was determined that working women in workers status has less maternity and breastfeeding rights than civil servants. Women stated that the ideal motherhood perception of the society do not recommend to continue to work during breastfeeding. Breastfeeding rooms at the work place where this study was conducted were found to be insufficient concerning quality and quantity. It was understood that maternity leave and breastfeeding breaks were insufficient and under the subjective control of superiors. It was reported that the breastfeeding permit periods of women were not favored by other employees at the workplace. It was determined that women who had ideal motherhood perception felt guilty about thinking that they could not care enough about their babies during their working hours.

\section{Disclosures}

Peer-review: Externally peer-reviewed.

Conflict of Interest: None declared.

Funding Sources: There is no funding in this article Disclosures.
Ethics Committee Approval: To carry out thisstudy, the approval of ESOGUNon-Drug Clinical Research Ethics Committee dated 26 June 2014 and numbered 80558721/196 was obtained.

Authorship Contributions: Concept - E.A., A.Ü.; Design - E.A.; Supervision - A.Ü.; Materials - E.A.; Data collection \&/or processing - E.A; Analysis and/or interpretation - E.A., A.Ü., D.A.; Literature search - E.A; Writing - E.A.; Critical review - A.Ü., D.A

\section{REFERENCES}

1. Gartner LM, Morton J, Lawrence RA, Naylor AJ, O'Hare D, Schanler RJ, et al, Breastfeeding and the use of human milk. Pediatrics 2005;115(2):496-506. [CrossRef]

2. Hannula L, Kaunonen M, Tarkka MT. A systematic review of professional support interventions for breastfeeding. J Clin Nurs 2008;17(9):1132-43. [CrossRef]

3. Word Health Organization. Available at: https://www.who.int/ nutrition/publications/infantfeeding/en/. Accessed Jan 31, 2020.

4. Innocenti Declaration 2005. Available at: https://www.unicef. org/nutrition/files/innocenti2005m_FINAL_ARTWORK_3_ MAR.pdf. Accessed Jan 31, 2020.

5. Kurtuluş Yiğit E, Tezcan S, Tunçkanat H. Çocukların ve annelerin beslenme durumu. Hacettepe Üniversitesi Nüfus Etütleri Enstitüsü, Türkiye Nüfus ve Sağlık Araştırması, 2008. p. 171-5.

6. Scott JA, Binns CW, Oddy WH, Graham KI. Predictors of breastfeeding duration: evidence from a cohort study. Pediatrics 2006;117(4):e646-55. [CrossRef]

7. Bakiler AR, Özgür S, Özer EA. Anne sütü ile beslenmeyi etkileyen faktörler. İzmir Tepecik Hastanesi Dergisi 2005;15(2):111-5.

8. Gökçay G, Baslo G. Anne sütü ile beslenmede kanıta dayalı uygulamalar II: Yetersiz anne sütü, çalışan anne, ilaçlar ve hastalıklar. Çocuk Dergisi 2002;2:139-43.

9. Win NN, Binns CW, Zhao Y, Scott JA, Oddy WH. Breastfeeding duration in mothers who express breast milk: a cohort study. Int Breastfeed J 2006;1:28. [CrossRef]

10. Ünsal H, Atlıhan F, Özkan H, Targan Ş, Hassoy H. Toplumda anne sütü verme eğilimi ve buna etki eden faktörler. Çocuk Sağlığı ve Hastalıkları Dergisi 2005;48:226-33.

11. Eskişehir Osmangazi Üniversitesi. Available at: https://www. ogu.edu.tr/. Accessed Jan 31,2020.

12. Gebe veya Emziren Kadınların Çalıştırılma Şartlarıyla Emzirme Odaları ve Çocuk Bakım Yurtlarına Dair Yönetme, Resmi Gazete. Available at: https://www.resmigazete.gov.tr/eskiler/2013/08/20130816-8.htm. Accessed Jan 31, 2020.

13. de Onis M, Dewey KG, Borghi E, Onyango AW, Blössner M, Daelmans $B$, et al. The World Health Organization's global target for reducing childhood stunting by 2025: rationale and proposed actions. Matern Child Nutr 2013;9:6-26. [CrossRef]

14. International Labor Organization. Geleceğin korunması: annelik babalık ve çalışma. Available at: https://www.ilo.org/ wcmsp5/groups/public/@dgreports/@gender/documents/ 
publication/wcms_120428.pdf. Accessed Jan 31, 2020.

15. Addati L, Cassirer N, Gilchrist K. Maternity and paternity at work: Law and practice across the world. International Labour Office. Available at: https://www.ilo.org/wcmsp5/groups/ public/---dgreports/---dcomm/---publ/documents/publication/wcms_242615.pdf. Accessed Jan 31, 2020.

16. International Labor Organization. C183 - Maternity Protection Convention, 2000 (No. 183). Available at: https://www.ilo.org/ dyn/normlex/en/f?p=NORMLEXPUB:12100:0::NO::P12100_ ILO_CODE:C183. Accessed Jan 31, 2020.

17. Smith PH. Breastfeeding and Gender Inequality. J Hum Lact 2018;34(2):220-5. [CrossRef]

18. Brown CA, Poag S, Kasprzycki C. Exploring large employers' and small employers' knowledge, attitudes, and practices on breastfeeding support in the workplace. J Hum Lact 2001;17(1):39-46. [CrossRef]

19. Atabay E, Moreno G, Nandi A, Kranz G, Vincent I, Assi TM, et al. Facilitating Working Mothers' Ability to Breastfeed Global Trends in Guaranteeing Breastfeeding Breaks at Work, 19952014. J Hum Lact 2015;31(1):81-8. [CrossRef]

20. Lakati A, Binns C, Stevenson M. The effect of work status on exclusive breastfeeding in Nairobi. Asia Pac J Public Health 2002;14(2):85-90. [CrossRef]

21. Yilmaz G, Gürakan B, Akgün S, Ozbek N. Factors influencing breastfeeding for working mothers. Turk J Pediatr 2002;44(1):30-4.

22. Ortiz J, McGilligan K, Kelly P. Duration of breast milk expression among working mothers enrolled in an employer-sponsored lactation program. Pediatr Nurs 2004;30(2):111-9.

23. Rojjanasrirat W. Working women's breastfeeding experiences. MCN Am J Matern Child Nurs 2004;29(4):222-7. [CrossRef]

24. Stevens KV, Janke J. Breastfeeding experiences of active duty military women. Mil Med 2003;168(5):380-4. [CrossRef]

25. Tang L, Lee AH, Binns CW. Factors associated with breastfeeding duration: A prospective cohort study in Sichuan Province, China. World J Pediatr 2015;11(3):232-8. [CrossRef]

26. Witters Green R. Increasing breastfeeding rates in working mothers. Fam Sys Health, 2003;21(4):415. [CrossRef]

27. Christup HW. Litigating a Breastfeeding and Employment Case in the New Millennium. Yale JL \& Feminism, 2000;12(2):26386.

28. Kozhimannil KB, Jou J, Gjerdingen DK, McGovern PM. Access to workplace accommodations to support breastfeeding after passage of the Affordable Care Act. Womens Health Issues 2016;26(1):6-13. [CrossRef]

29. Dodgson JE, Chee YO, Yap TS. Workplace breastfeeding support for hospital employees. J Adv Nurs 2004;47(1):91-100.

30. Canbaz S, Sünter TA, Süren C, Pekşen Y. Fertility Characteristics of Female Health Employees and Working Conditions Following Pregnancy and Birth. The Medical Journal of Kocatepe 2005;6:39-44.

31. Greene SW, Olson BH. Development of an instrument designed to measure employees' perceptions of workplace breastfeeding support. Breastfeed Med 2008;3(3):151-7.

32. Stewart-Glenn J. Knowledge, perceptions, and attitudes of managers, coworkers, and employed breastfeeding mothers. AAOHN J 2008;56(10):423-9. [CrossRef]

33. Dabritz HA, Hinton BG, Babb J. Evaluation of lactation support in the workplace or school environment on 6-month breastfeeding outcomes in Yolo County, California. J Hum Lact 2009;25(2):182-93. [CrossRef]

34. Zhang $Y$, Jin $Y$, Vereijken C, Stahl B, Jiang H. Breastfeeding experience, challenges and service demands among Chinese mothers: A qualitative study in two cities. Appetite 2018;128:263-270. [CrossRef]

35. Badinter E. Kadınlık mı Annelik mi,?. 3rd ed. İstanbul: İletişim Yayınları; 2017.

36. Smith PH, Hausman B, Labbok M. Beyond Health, Beyond Choice: Breastfeeding Constraints and Realities. Rutgers University Press; 2012.

37. Bağlı M, S Sevim. Popüler Anababalık: Aile Dergileri Üzerine Bir Araştırma. V. Ulusal Çocuk Kültürü Kongresi Popüler Kültür ve Çocuk Popüler Kültür ve Çocuk. Ankara: İmge Yayınevi; 2007. p. 127-58.

38. Işık SY. Globalization, Cultural Change and Parenthood: Ankara Kamil Ocak Neighborhood Sample. (dissertation). Ankara: Hacettepe University. 2013. 